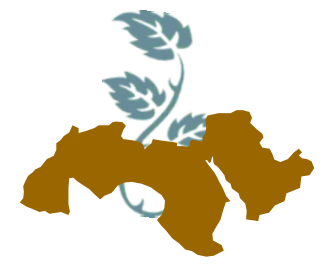

Arab Univ.

J. Agric. Sci., Ain Shams Univ., Cairo, 25(2), 259-269, 2017

\title{
EFFECT OF STRAIN, SEASON AND BREEDER'S AGE ON SOME PHYSIOLOGICAL PARAMETERS FOR LAYER DEAD EMBRYO
}

\author{
Abd El-Salam, A.M. ${ }^{2}$; Eman, F. El-Daly²; Y.A. Hamouda ${ }^{2}$; \\ S.A. El-Safty ${ }^{1}$ and A.H. El-Attar ${ }^{1}$ \\ 1- Poultry Production Dept. Faculty of Agriculture, Ain Shams University, Cairo, Egypt. \\ 2- Animal production Dept., National Research Center, Dokki, Egypt
}

Keywords: Strain, Season, Age, Demand organs, Supply organs and lymphoid organs

\section{ABSTRACT}

The effect of breeder's strain (Hy-line Brown and Hy-line White W36) flock aged $(28,36,46,55$, 66 weeks of age) and breeding season on some physiological measurements in egg, demand organs, dead supply organs and lymphoid organs were examined. At each age, 10 unhatched eggs from each genotype were examined on embryo weight percentage, Chorioallotoic weight \%, albumen $\mathrm{pH} \%$, yolk $\mathrm{pH} \%$, residual yolk \%, pectoral muscles weight $\%$, hatch muscles weight $\%$, heart, liver, lunges, spleen, burse weight percentage. There was a significant difference between layer breeder genotypes for lunges weight percentage the brown was higher $(0.84)$ than the white $(0.62)$. The breeding season had a significant effect on heart, liver, lunges weight percentages in winter higher than summer but yolk $\mathrm{pH}$ and residual yolk the summer higher than the winter. Breeder's age significant effect on embryo weight percentage, Chorioallotoic weight \%, albumen $\mathrm{pH} \%$, yolk $\mathrm{pH} \%$, residual yolk \%, hatch muscles weight \% heart, liver, lunges and burse weight percentage. It could be observed that the genetic differences among layer breeder strain and age of breeders can affect the hatchery performance. Additionally, handling of hatching eggs and incubation management can play a major role to overcome numerous hatching problems. In turn, increasing the production of table eggs and achieves the balance between supply and demand of that strategic commodity in Egyptian market.

\section{INTRODUCTION}

Poultry production had improved linearly each year during the past four decades (Havenstein et al 2007) and this trend is likely to continue in the future as new technologies in genetics, biotechnology and developmental biology are adopted by the poultry industry. The last phase of embryogenesis is characterized by oral consumption of the amnion by the embryo, accumulation of glycogen reserves in muscle and liver tissues and glycogenolys is initiation of pulmonary respiration, abdominal internalization of remaining yolk, shell pipping and emergence (Moran, 2007). During this period, dramatic physiological and metabolic changes occur and any disturbances during this period may markedly affect embryonic survival and later performance (Collin et al 2007 and Leksrisompong et al 2007).

The age of hens is another factor influencing egg weight. Rizzi and Chiericato (2005) and Johnston and Gous (2007) showed that the egg weight increased with the hen's age. On the other hand, Zemková et al (2007) demonstrated that the egg weight was not significantly influenced by age. The age of hens also increased yolk weight (Suk \& Park, 2001 and Van den Brand et al 2004) albumen weight (Suk and Park, 2001) and yolk proportion (Rizzi and Chiericato, 2005), but decreased albumen percentage (Van den Brand et al 2004 and Rizzi \& Chiericato, 2005). Higher albumen percentage in young breeder's eggs and the higher yolk percentage in old breeder's eggs were also reported by Gomes et al (2005a) and Vieira et al (2005). Almeida et al (2008) disclosed that breeder's age influenced yolk sac weight relative to chick 
weight. Yalçın (2008) reported that during the embryonic period and on day old chick absolute weights of liver, heart, and breast were also heavier in chicks from older parents. Organ weights relative to chick weight without yolk sac did not change the lack of effect of parental age. Yildirim (2005) pointed albumen $\mathrm{pH}$ and yolk $\mathrm{pH}$ were higher $(P \leq 0.05)$ in old breeder eggs than in those from the young breeders.

Tůmová et al (1993) demonstrated significant effect of strain on yolk weight and percentage in Hisex Brown eggs than in D-29 with white eggs. In contrast, Leyendecker et al (2001b) showed significantly higher yolk weight in egg of white chickens (Lohmann LSL) in comparison with the tradition Lohmann brown. D

ruyan (2010) pointed out there was no differences among the 3 lines (two are broilers, Cobb and Ross) and the third is layer (Lohmann) for liver, breast muscle and heart relative weights, at any developmental stage. Embryonic relative weights were not affected by flock age patterns, they was similar for breeder flock aged 31-wk and 38-wk. Tona et al (2010) disclosed that albumen $\mathrm{pH}$ of Lohman brown eggs was lower than that of Lohman white eggs at day 8 of incubation.

The embryonic stress response resulting from the continued presence of transponders in the egg air cells may be assessed by examining the relative weights of lymphoid organs such as the spleen and bursa of Fabricius (Glick, 1967; Puvadolpirod and Thaxton, 2000a, b, c).

Van de Ven et al (2013) reported that hatch time influenced bursa weight. There results showed that early hatch $(E H)$ chicks had relative weights of bursas similar to those of late hatch (LH). The spleen weight of EH chicks was heavier than that of $\mathrm{LH}$ chicks $(P \leq 0.05)$. Because spleen and bursa are the main lymphoid organs of the immune system, the heavier weights may show the early maturation of the organs of $\mathrm{EH}$ chick. ElSabry et al (2013) found that the breeder's age did not significant affected relative lymphoid organ weights.

The study of muscle development during the embryonic stage is a popular research focus. A number of studies have investigated muscle development during the embryonic stage in different species (Callis et al 2007; Williams et al 2009 and Zhang et al 2012).

The complexes muscle or hatching muscle is located in the back of the head, right under the skull (Gross, 1985). Its primary function is to help the embryo pierce the membranes and the shell during hatching (Feher, 1988 and Moran, 2007). The hatching muscle increases in size towards the time of pipping, and then regresses some days after hatch (John et al 1987). Enlargement of the hatching muscle by the large accumulation of water and glycogen granules provides the resources for vigorous contractions that force the egg -tooth to puncture the shell membranes.

The pectoral or breast muscle (pectoral's major) of the avian embryo is metabolially important mainly because of its relatively large size and glycogen storage capacity. Even though, the pectoral muscle contains less glycogen per unit of mass than the liver, it accounts for the greatest quantity of total glycogen stored in the body (Uni et al 2005 and Foye et al 2006). The pectoral muscle is the predominant source of protein mobilized to supply amino acids for gluconeogenesis is if energy reserves are depleted after hatch Warner et al (2006). Therefore, it is important to study the pectoral muscle when tracking the destiny of circulating glucose during late incubation.

\section{MATERIAL AND METHODS}

Ten samples of eggs from two strains of layer breeder eggs (Hy-line brown and $\mathrm{Hy}$-line white) in two production seasons (summer and winter) at different age of production (28, 36, 46, 55 and 66) weeks of age were taken to study the physiological parameters. The unhatched eggs were weighted after that, Eggs were broken, the embryo weight percentage, residual yolk weight were calculated and extract the chorioallotoic membrane without shell membrane and weight. The $\mathrm{pH}$ of the egg yolk and albumen was measured using $\mathrm{pH}$ meter after diluting the sample with $3 \mathrm{v}$ of deionized distilled water (El-sabry et al 2013). Extract the breast muscle and calculated the relative weight, hatching muscle was removed from back neck the embryo and calculated the relative weight. The heart, liver, lungs, spleen and bursa of fabricius weight were measured as a percentage of embryo weight.

\section{Statistical analysis}

All data were analyzed using three way analysis of variance with breeder strain, flock age and season of egg production effects and their interactions using General Liner Model (GLM) procedure of SAS User's Guide (2009) according to the following model; 

for layer dead embryo

$Y i j k f=\mu+S t i+S e j+A k+\left(S t^{*} S e\right) i j+\left(S t^{*} A\right) i k+$ $\left(S e^{\star} A\right) j k+\left(S t^{*} S e^{\star} A\right) i j k+E i j k f$

$\mu=$ overall means,

Sti= breeder strains effect $(i=1,2)$,

$\mathrm{Sej}=$ Season of egg production $(j=1,2)$,

$A k=$ layer breeder flock age $(k=1, . ., 5)$,

$\left(\mathrm{St}{ }^{*} \mathrm{Se}\right) \mathrm{ij}=$ interaction between strain and season,

$\left(S t^{\star} A\right) i k=$ interaction between strain and age,

$\left(S e^{\star} A\right) j k=$ interaction between season and age,

$\left(S^{*} S e^{*} A\right) i j k=$ interaction between strain, season and age,

$E \mathrm{ijkf}=$ Experimental error.

\section{RESULTS AND DISSECTION}

1- Effect of strain, season and breeder's age on measurements in egg

Data in Table (1) showed that effect of strain on embryo weight percentage did not significant. Season did not significantly affect the percentage of embryo weight. Breeder's age was significantly affected the embryo weight percentage $(P \leq 0.01)$. Embryo development is affected by the breeder's age (Azzam \& Mortola, 2007; Everaert et al 2008 and Mortola \& Al Awam, 2010).

The interaction between breeder's age and strain and between age and season were significant $(P \leq 0.05)$, values recorded of embryo weight percentage showed that in winter season the brown strain was lower $(82.76 \%)$ than the white strain $(82.99 \%)$. In contrast in summer season the value of white strain recorded lower $(80.85 \%)$ than the brown one (83.28\%). Druyan (2010) reported that the interactions between strain and flock age had no significant effect on relative embryo weight, which generally increased as the flock aged $(P<$ 0.001 for parental flock age).

Chorioallotoic weight percentage data showed that either strain or season did not significantly affect such parameter throughout the experimental period. The breeder's age affected chorioallotoic percentage significantly $(P \leq 0.001)$. The interaction between strain and age was significant $(P \leq 0.01)$. However, the interaction between strain, season and age was significant $(P \leq 0.001)$. Zamudio (2003) demonstrated that the increase in chorioallotoic membrane (CAM) weight, presumably improves its $\mathrm{O}_{2}$ diffusion capacity through the proliferation of additional gas exchange vessels and the extra surface area they provide, which would minimize the detrimental effects of hypoxia on development and growth.
Albumen $\mathrm{pH}$ data showed that either strain or season did not significantly affect albumen $\mathrm{pH}$ throughout the experimental period. Our results disagreed with Tona (2010), who found that average albumen $\mathrm{pH}$ of Lohmann brown (LB) eggs was significantly lower than that of Lohman white (LW) eggs $(P<0.01)$. The breeder's age effect albumen $\mathrm{pH}(\mathrm{P} \leq 0.05)$. Brake et al (1997) reported that albumen $\mathrm{pH}$ at oviposition was about 7.6 and rose to about 9.0 during storage. However, Yildirim (2005) albumen $\mathrm{pH}$ was not significantly influenced by flock age.

Data concerning the interaction between strain and season and between breeder's age and season were not significant. But, the interaction between strain and breeder's age and strain, season and breeder's age were significant at $(P \leq 0.05)$. (Reijrink et al 2008 and El-Sabry et al 2013) reported that albumen $\mathrm{pH}$ deemed to be around it's optimum values being similar for eggs from both flock ages.

Tona (2010) stated that change in egg albumen $\mathrm{pH}$ during the early embryonic stage is related to the rate of embryo initiation and growth. Because the yolk remains slightly acid, an almost 1000 -fold hydrogen ion concentration gradient exists across the blastoderm in its position between albumen and yolk (Stern, 1991). Thus, changes in the viscosity or $\mathrm{pH}$ of the albumen may play a role in determining the viability of the embryo during early stages of development (Benton and Brake, 1996).

Yolk $\mathrm{pH}$ data showed that the strain did not significantly affect yolk $\mathrm{pH}$ throughout the experimental period. The breeder's age significantly effected on yolk $\mathrm{pH}(\mathrm{P} \leq \mathrm{0.001})$ also, season was significantly affected the $\mathrm{pH}$ yolk $(\mathrm{P} \leq 0.01)$. Our results disagreed with Yildirim (2005) reported that yolk $\mathrm{pH}$ was not significantly influenced by flock age.

The recorded data for age effects showed that the highest value recorded for the $66^{\text {th }}(7.82)$ week of age, followed by $28^{\text {th }}(7.76), 36^{\text {th }}(7.75), 55^{\text {th }}$ (7.70) and $46^{\text {th }}(7.56)$, respectively. (Reijrink et al 2008 and El-Sabry et al 2013) found yolk $\mathrm{pH}$ deemed to be around it is optimum value being similar for eggs from both breeder's ages.

Data concerning the interactions between strain and season and between strain, season and age were not significant. But, the interaction between strain and age was significant ( $P \leq 0.05)$. The interaction between season and age was significant at $(P \leq 0.001)$. 
Table 1. Effect of strain, season and breeder's age on measurements in egg

\begin{tabular}{|c|c|c|c|c|c|c|c|c|c|}
\hline & \multicolumn{2}{|c|}{ Strain } & \multicolumn{2}{|c|}{ Season } & \multicolumn{5}{|c|}{ Age } \\
\hline & White & Brown & Summer & Winter & 28 & 36 & 46 & 55 & 66 \\
\hline $\begin{array}{l}\text { Embryo } \\
\text { weight \% }\end{array}$ & $\begin{array}{l}81.92 \\
\pm 2.14\end{array}$ & $\begin{array}{l}83.02 \\
\pm 3.00\end{array}$ & $\begin{array}{l}82.87 \\
\pm 2.29\end{array}$ & $\begin{array}{l}82.06 \\
\pm 2.84 \\
\end{array}$ & $\begin{array}{c}82.57^{\mathrm{ab}} \\
\pm 2.54\end{array}$ & \begin{tabular}{|c|}
$84.47^{\mathrm{ab}}$ \\
\pm 2.3
\end{tabular} & $\begin{array}{c}86.62^{a} \\
\pm 1.91\end{array}$ & $\begin{array}{l}77.51^{\mathrm{c}} \\
\pm 2.98\end{array}$ & $\begin{array}{c}81.17^{\mathrm{bc}} \\
\pm 3.11\end{array}$ \\
\hline $\begin{array}{c}\text { Chorioallotoic } \\
\text { weight } \%\end{array}$ & $\begin{array}{c}2.00 \\
\pm 0.47\end{array}$ & $\begin{array}{c}1.89 \\
\pm 0.32\end{array}$ & $\begin{array}{c}2.1 \\
\pm 0.45\end{array}$ & $\begin{array}{c}1.8 \\
\pm 0.34\end{array}$ & $\begin{array}{l}2.46^{\mathrm{a}} \\
\pm 0.61\end{array}$ & $\begin{array}{c}1.5725^{\mathrm{b}} \\
\pm 0.32\end{array}$ & $\begin{array}{l}1.485^{\mathrm{b}} \\
\pm 0.36\end{array}$ & $\begin{array}{l}3.04^{\mathrm{a}} \\
\pm 0.40\end{array}$ & $\begin{array}{l}1.22^{\mathrm{b}} \\
\pm 0.29\end{array}$ \\
\hline albumen $\mathrm{pH}$ & $\begin{array}{c}7.95 \\
\pm 0.077\end{array}$ & $\begin{array}{c}8.008 \\
\pm 0.076\end{array}$ & $\begin{array}{c}8.018 \\
\pm 0.078\end{array}$ & $\begin{array}{c}7.942 \\
\pm 0.0755\end{array}$ & $\begin{array}{r}8.035^{\mathrm{a}} \\
\pm 0.0775\end{array}$ & $\begin{array}{l}7.915^{\mathrm{ab}} \\
\pm 0.075\end{array}$ & $\begin{array}{l}7.895^{\mathrm{b}} \\
\pm 0.075\end{array}$ & $\begin{array}{c}7.86^{\mathrm{b}} \\
\pm 0.1075\end{array}$ & $\begin{array}{c}7.945^{\mathrm{ab}} \\
\pm 0.04875\end{array}$ \\
\hline yolk pH & $\begin{array}{c}7.752 \\
\pm 0.076\end{array}$ & $\begin{array}{c}7.688 \\
\pm 0.083\end{array}$ & $\begin{array}{c}7.77^{\mathrm{a}} \\
\pm 0.082\end{array}$ & $\begin{array}{c}7.67^{\mathrm{b}} \\
\pm 0.077\end{array}$ & $\begin{array}{c}7.76^{\mathrm{a}} \\
\pm 0.075\end{array}$ & $\begin{array}{l}7.755^{\mathrm{a}} \\
\pm 0.095\end{array}$ & $\begin{array}{r}7.56^{\mathrm{b}} \\
\pm 0.0625\end{array}$ & $\begin{array}{c}7.7^{a} \\
\pm 0.0825\end{array}$ & $\begin{array}{c}7.825^{\mathrm{a}} \\
\pm 0.0825\end{array}$ \\
\hline \multirow[t]{3}{*}{ Residual yolk \% } & $\begin{array}{r}18.75 \\
\pm 3.24 \\
\end{array}$ & $\begin{array}{l}20.42 \\
\pm 6.26 \\
\end{array}$ & $\begin{array}{l}22.14^{\mathrm{a}} \\
\pm 7.031\end{array}$ & $\begin{array}{c}42.56^{\mathrm{b}} \\
\pm 6.18 \\
\end{array}$ & \begin{tabular}{|c|}
$19.80^{\mathrm{ab}}$ \\
\pm 3.32 \\
\end{tabular} & $\begin{array}{c}16.27^{b} \\
\pm 3.27\end{array}$ & $\begin{array}{l}23.61^{\mathrm{a}} \\
\pm 2.41 \\
\end{array}$ & $\begin{array}{c}16.13^{\mathrm{b}} \\
\pm 5.43 \\
\end{array}$ & $\begin{array}{c}22.10^{\mathrm{a}} \\
\pm 9.31 \\
\end{array}$ \\
\hline & \multicolumn{9}{|c|}{ Pro } \\
\hline & Strains & Season & Age & $\mathrm{St}^{*} \mathrm{Se}$ & $\mathrm{St}^{*} \mathrm{~A}$ & $\mathrm{Se}^{\star} \mathrm{A}$ & \multicolumn{3}{|c|}{$\mathrm{ST}^{\star} \mathrm{Se}^{\star} \mathrm{A}$} \\
\hline $\begin{array}{c}\text { Embryo } \\
\text { weight \% }\end{array}$ & NS & NS & ** & NS & * & * & \multicolumn{3}{|c|}{ NS } \\
\hline $\begin{array}{l}\text { Chorioallotoic } \\
\text { Weight \% }\end{array}$ & NS & NS & $* * *$ & NS & ** & NS & \multirow{2}{*}{\multicolumn{3}{|c|}{$* \star *$}} \\
\hline albumen $\mathrm{pH} \%$ & NS & NS & * & NS & * & NS & & & \\
\hline yolk pH \% & NS & ** & $* * *$ & NS & * & $* * *$ & \multicolumn{3}{|c|}{ NS } \\
\hline residual Yolk \% & NS & $* * *$ & $* *$ & NS & * & NS & \multicolumn{3}{|c|}{ ** } \\
\hline
\end{tabular}

$a, b$ and $c$ Means within the same column with different letters are significantly differed. $S t=$ strain, $S e=s e a s o n, A=$ age, NS= not significant, ${ }^{*}=\mathrm{P} \leq 0.05,{ }^{* *}=\mathrm{P} \leq 0.01,{ }^{* \star *}=\mathrm{P} \leq 0.001$

Residual yolk percentage data showed that the strain did not significantly affect yolk percentage throughout the experimental period. Our results disagreed with Wolanski et al (2006) reported that residual yolk mass can be extremely variable among genetic strains at the hatch, ranging from 0.8 to $10.6 \mathrm{~g}$. Wolanski et al (2007) stated that yolk weight varied with genetic strain. Oke et al (2015) reported that strain significantly $(P<0.05)$ affected the percentage of egg yolk weight. The breeder's age was significantly $(P \leq 0.01)$ effected on yolk percentage. The studied parameter was significantly affected by season ( $P \leq 0.001)$. Our results agreed with Padhi et al (2013) found that yolk weight increases as the breeder's age advances, whereas albumen weight decreased significantly at 72 weeks of age compared to 40,52 and 64 weeks of age. They also, stated that Correlation coefficient between egg weight and yolk, albumen were positive. The lower yolk \% at early ages may be suitable for the consumer who needs less yolk \% and can be used for table purpose.
Increase in yolk \% compared to earlier ages is in agreement with the reports of Silversides and Scott (2001) and Tumova and Gous (2012). Increasing yolk weight with an increase chickens age was reported by (Niranjan et al 2008 and Rajkumar et al 2009).

Oke et al (2015) stated that the yolk sac begins to enter the body cavity on $19^{\text {th }}$ day of incubation. The yolk is completely drawn into the body on $20^{\text {th }}$ day (Christensen, 2009).

The recorded data for the effect of season on the studied parameter showed that, winter recorded lower $(22.14 \%)$ than in summer $(42.56 \%)$. The highest value recorded in winter was found in the $46^{\text {th }}$ weeks of age $(27.64 \%)$. Also, the highest value in summer was $46^{\text {th }}(19.58 \%)$.

The breeder's age significantly affected this parameter. The highest value recorded for the $46^{\text {th }}$ $(23.61 \%)$ weeks of age, followed by $66^{\text {th }}(22.10 \%)$, $28^{\text {th }}(19.80 \%), 36^{\text {th }}(16.27 \%)$ and $55^{\text {th }}(16.13 \%)$, respectively. Our results in accordance with Almeida et al (2008) who observed that, significant 

for layer dead embryo

relations were recorded for higher relative yolk weight for old breeders eggs, while eggs from young and intermediate breeder's age did not present any differences in these parameter, and the higher yolk percentage in old breeders eggs were also found by Vieira et al (2005) and Gomes et al (2005a). Yalçın et al (2008) demonstrated that Proportional and absolute yolk weights increased significantly with age of breeder parent $(65>42>$ $32 \mathrm{wk})$.

The interaction between strain and age was significant $(P \leq 0.05)$. Moreover, the interaction between strain, season and age was significant $(P$ $\leq 0.01)$. Wolanski et al (2007) Obtained that both age and strain may influence the weight of internal contents (yolk and albumen) and composition of the hatching eggs. Druyan (2010) using 38-week broiler lines, he revealed that relative yolk weights decreased significantly compared with those of embryos from the 31-week flock causing a significant interaction $(P=0.008)$ between line and flock age.

Uni et al (2012) found that absorption of yolk fat up to day $15^{\text {th }}$ was lower in embryos from younger hens than in those from older hens perhaps because of the lower initial yolk fat content in the eggs of the younger hens.

Although, no significant difference in the interaction between strain and season, values recorded for these parameters showed that in winter season the brown strain was higher $(22.42 \%)$ than the white strain $(21.87 \%)$. On the contrary, in summer season the white strain recorded lower values $(17.02 \%)$ than the brown one $(22.14 \%)$.

The reason for failed out of embryo may be due to decrease of minerals that detrimental the growth and development of embryos. Kidd (2003), Angel (2007) and Dibner et al (2007) found a mineral is very important to the growth and development of embryos. A mineral deficiency can cause skeletal, immune and cardiovascular system disorders, reduced hatchability and increased mortality.

\section{2- Effect of strain, season and breeder's age on Demand organs measurements}

Data in Table (2) showed that pectoral muscles weight percentage data showed that the strain, season and age did not significantly affect pectoral muscles weight percentage throughout the experimental period. Similarly, Druyan (2010) stated that no difference among the lines was recorded in breast muscle relative weights at any developmental stage. Our results disagreed with Yalçın et al
(2008) found that during the embryonic period absolute weights of breast were also heavier from older parents

Data concerning the interactions between the main factors strain, season and age did not significantly affect such parameter.

Hatching muscles weight percentage data showed that the strain and season did not significantly affect hatching muscle weight percentage throughout the experimental period. However, the breeder's age effect on the hatching muscle weight percentage was significant $(P \leq 0.001)$.

The primary function of hatching muscles is to help the embryo pierces the membranes and the shell during hatching Moran (2007). The hatching muscles increases in size towards the time of pipping and then regress some days after hatch (John et al 1987). Enlargement of the hatching muscles by the large accumulation of water and glycogen granules provides the resources for vigorous contractions that force the egg-tooth to puncture the shell membranes. Pulikanti et al (2010) found that pipping muscle of broiler embryos increased relative to their body weight.

Data concerning the interaction between strain and season, strain and breeders age and strain, were not significant. However, the interaction between season and breeders age was significant $(P \leq 0.01)$.

\section{3- Effect of strain, season and breeder's age on supply organs}

The data in Table (3) showed that heart weight percentage the strain did not significantly affected these parameters throughout the experimental period. Heart weight percentage significantly affected by breeder's age ( $P \leq 0.001)$. The season effect on the studied parameter had significant effect $(P \leq 0.01)$. Our results disagreed with Xiangguang (2013) who reported the relative heart weight on day of hatch was significantly higher $(\mathrm{P} \leq$ 0.01) in different strain. However, Druyan (2010) recorded that there was no difference among the lines in heart relative weight, at any developmental stage. Yalçın et al (2008) pointed out that Parental age affected embryo weight, with embryos being heavier from older than from younger flocks. During the embryonic period, absolute weight heart was also heavier from older parents. Moreover, Yildirim (2005) heart weight as a percentage of chick weight was higher $(P<0.05)$ in chicks produced from breeders after starting production by 10 week than from 40 week old breeders. 
Table 2. Effect of strain, season and breeder's age on demand organs measurements

\begin{tabular}{|c|c|c|c|c|c|c|c|c|c|}
\hline & \multicolumn{2}{|c|}{ Strain } & \multicolumn{2}{|c|}{ Season } & \multicolumn{5}{|c|}{ Age } \\
\hline & White & Brown & Summer & Winter & 28 & 36 & 46 & 55 & 66 \\
\hline $\begin{array}{l}\text { Pectoral muscles } \\
\text { weight } \%\end{array}$ & $\begin{array}{c}2.04 \\
\pm 0.29\end{array}$ & $\begin{array}{c}2.17 \\
\pm 0.25\end{array}$ & $\begin{array}{l}2.017 \\
\pm 0.24\end{array}$ & $\begin{array}{r}2.19 \\
\pm 0.29\end{array}$ & $\begin{array}{c}2.02 \\
\pm 0.24\end{array}$ & $\begin{array}{r}2.00 \\
\pm 0.35\end{array}$ & $\begin{array}{c}2.08 \\
\pm 0.18\end{array}$ & $\begin{array}{c}2.11 \\
\pm 0.28\end{array}$ & $\begin{array}{r}2.30 \\
\pm 0.29\end{array}$ \\
\hline \multirow[t]{3}{*}{$\begin{array}{c}\text { Hatch muscles } \\
\text { weight } \%\end{array}$} & $\begin{array}{r}0.50 \\
\pm 0.14 \\
\end{array}$ & $\begin{array}{r}0.49 \\
\pm 0.07 \\
\end{array}$ & $\begin{array}{r}0.45 \\
\pm 0.07 \\
\end{array}$ & $\begin{array}{c}0.54 \\
\pm 0.14 \\
\end{array}$ & $\begin{array}{l}0.38^{\mathrm{bc}} \\
\pm 0.16\end{array}$ & $\begin{array}{l}0.25^{c} \\
\pm 0.06\end{array}$ & $\begin{array}{l}0.45^{\mathrm{bc}} \\
\pm 0.06\end{array}$ & $\begin{array}{l}0.57^{b} \\
\pm 0.08\end{array}$ & $\begin{array}{l}0.82^{a} \\
\pm 0.16\end{array}$ \\
\hline & \multicolumn{9}{|c|}{ Pro } \\
\hline & Strains & Season & Age & $\mathrm{St}^{\star} \mathrm{Se}$ & $S t^{\star} A$ & $\mathrm{Se}^{\star} A$ & \multicolumn{3}{|c|}{$\mathrm{ST}^{\star} \mathrm{Se}^{\star} \mathrm{A}$} \\
\hline $\begin{array}{l}\text { Pectoral muscles } \\
\text { weight } \%\end{array}$ & NS & NS & NS & NS & NS & NS & \multicolumn{3}{|c|}{ NS } \\
\hline $\begin{array}{c}\text { Hatch muscles } \\
\text { weight } \%\end{array}$ & NS & NS & $* * *$ & NS & NS & $* *$ & \multicolumn{3}{|c|}{ NS } \\
\hline
\end{tabular}

$a, b$ and $c$ Means within the same column with different letters are significantly differed. St= strain, $\mathrm{Se}=$ season, $\mathrm{A}=$ age, $\mathrm{NS}=$ not significant, ${ }^{*}=\mathrm{P} \leq 0.05,{ }^{* *}=\mathrm{P} \leq 0.01,{ }^{* * *}=\mathrm{P} \leq 0.001$

Table 3. Effect of strain, season and breeder's age on supply organs

\begin{tabular}{|c|c|c|c|c|c|c|c|c|c|}
\hline & \multicolumn{2}{|c|}{ Strain } & \multicolumn{2}{|c|}{ Season } & \multicolumn{5}{|c|}{ Age } \\
\hline & White & Brown & Summer & Winter & 28 & 36 & 46 & 55 & 66 \\
\hline $\begin{array}{c}\text { Heart } \\
\text { weight \% }\end{array}$ & $\begin{array}{c}1.78 \\
\pm 0.22\end{array}$ & $\begin{array}{c}1.94 \\
\pm 0.18\end{array}$ & $\begin{array}{l}0.46^{\mathrm{b}} \\
\pm 0.04\end{array}$ & $\begin{array}{c}0.59^{\mathrm{a}} \\
\pm 0.09\end{array}$ & $\begin{array}{l}0.42^{b} \\
\pm 0.03\end{array}$ & $\begin{array}{l}0.40^{\mathrm{b}} \\
\pm 0.05\end{array}$ & $\begin{array}{l}0.65^{a} \\
\pm 0.12\end{array}$ & $\begin{array}{l}0.48^{b} \\
\pm 0.05\end{array}$ & $\begin{array}{l}0.68^{a} \\
\pm 0.09\end{array}$ \\
\hline $\begin{array}{c}\text { Liver } \\
\text { weight \% }\end{array}$ & $\begin{array}{c}1.78 \\
\pm 0.22\end{array}$ & $\begin{array}{c}1.94 \\
\pm 0.18\end{array}$ & $\begin{array}{l}1.72^{b} \\
\pm 0.15\end{array}$ & $\begin{array}{l}2.01^{a} \\
\pm 0.25\end{array}$ & $\begin{array}{l}1.36^{b} \\
\pm 0.16\end{array}$ & $\begin{array}{l}1.51^{\mathrm{b}} \\
\pm 0.18\end{array}$ & $\begin{array}{l}2.23^{a} \\
\pm 0.25\end{array}$ & $\begin{array}{l}2.20^{a} \\
\pm 0.19\end{array}$ & $\begin{array}{l}2.00^{a} \\
\pm 0.23\end{array}$ \\
\hline \multirow[t]{2}{*}{$\begin{array}{c}\text { Lungs } \\
\text { weight \% }\end{array}$} & $\begin{array}{l}0.62^{\mathrm{b}} \\
\pm 0.08 \\
\end{array}$ & $\begin{array}{l}0.84^{a} \\
\pm 0.12 \\
\end{array}$ & $\begin{array}{l}0.61^{b} \\
\pm 0.09 \\
\end{array}$ & $\begin{array}{l}0.85^{\mathrm{a}} \\
\pm 0.14 \\
\end{array}$ & $\begin{array}{l}0.60^{\mathrm{b}} \\
\pm 0.10 \\
\end{array}$ & $\begin{array}{l}0.90^{\mathrm{a}} \\
\pm 0.16 \\
\end{array}$ & $\begin{array}{l}0.68^{b} \\
\pm 0.08 \\
\end{array}$ & $\begin{array}{l}0.53^{b} \\
\pm 0.08 \\
\end{array}$ & $\begin{array}{l}0.94^{\mathrm{a}} \\
\pm 0.13 \\
\end{array}$ \\
\hline & Strains & Season & Age & $\mathrm{St}^{\star} \mathrm{Se}$ & $S t^{\star} A$ & $S e^{\star} A$ & \multicolumn{3}{|c|}{$S T^{\star} \mathrm{Se}^{\star} \mathrm{A}$} \\
\hline $\begin{array}{c}\text { Heart } \\
\text { weight \% }\end{array}$ & NS & ** & *** & NS & *** & * & \multicolumn{3}{|c|}{ * } \\
\hline $\begin{array}{c}\text { Liver } \\
\text { weight \% }\end{array}$ & NS & * & $* * *$ & NS & * & $* * *$ & \multicolumn{3}{|c|}{ * } \\
\hline $\begin{array}{c}\text { Lungs } \\
\text { weight \% }\end{array}$ & $* * *$ & $* * *$ & $* * *$ & NS & $* * *$ & $* * *$ & \multicolumn{3}{|c|}{$* *$} \\
\hline
\end{tabular}

a, b and c Means within the same column with different letters are significantly differed. St= strain, $\mathrm{Se}=$ season, $\mathrm{A}=$ age, $\mathrm{NS}=$ not significant, ${ }^{*}=\mathrm{P} \leq 0.05,{ }^{* *}=\mathrm{P} \leq 0.01,{ }^{* * *}=\mathrm{P} \leq 0.001$ 

for layer dead embryo

The recorded data for the effect of season on the studied parameter showed that winter recorded lower $(0.46 \%)$ than in summer $(0.59 \%)$. The highest value recorded in winter was found in the $66^{\text {th }}$ weeks of age $(0.67 \%)$. While, the highest value in summer was $46^{\text {th }}(0.81 \%)$.

Data concerning the interaction between strain and season was not significant. But, the interaction between strain and breeders age was significant $(P \leq 0.001)$. The interaction between season and age and between strain, season and age was significant $(P \leq 0.05)$.

Liver weight percentage data showed that the strain had no significant effect throughout the experimental period. The breeder's age effect on the liver weight percentage was significant $(P \leq 0.001)$. While, the season effect in studied parameter had significant difference $(P \leq 0.05)$. Our results disagreed with Xiang-guang (2013) who demonstrated that significant differences in liver relative weight between strains. As the embryo becomes dependent on the ability of the liver to handle metabolic substrates (Lindgren and Altimiras, 2011) the general growth of the liver begins to dictate overall embryonic development. Druyan (2010) revolted that, no differences among the lines was recorded, in liver relative weights, at any developmental stage

In turkey's Christensen et al (1996) found that liver weight expressed as a percentage of whole body weight was greatest in embryos from eggs produced by young hens compared of those from the oldest hens. Moreover, Wolanski et al (2007) stated that, strains that had a significantly greater amount of residual yolk had significantly lower liver weights.

The breeder's age affects significantly this parameter. The highest value recorded for the $46^{\text {th }}$ $(2.23 \%)$ weeks of age, followed by $55^{\text {th }}(2.20 \%)$, $66^{\text {th }}(2.00 \%), 36^{\text {th }}(1.51 \%)$ and $28^{\text {th }}(1.36 \%)$, respectively. Our results agreed with Yalçın et al (2008), who found that, Parental age affected embryo weight, with embryos being heavier from older than from younger flocks. During the embryonic period, absolute weights of the liver were also heavier from older parents.

The interaction between strain and season was not significant. But, the interaction between season and breeder's age was significant $(P \leq 0.001)$. The interaction between strain and breeder's age and between strain, season and breeder's age was significant $(P \leq 0.05)$.
Lungs weight percentage data showed that the effect of the strain, season and breeder's age were significant $(P \leq 0.001)$ throughout the experimental period. Our results agreed with Xiang-guang Li, (2013) who found that, the increasing relative weight of the lung between strains, imply a functional requirement for the development of respiration, excretion and motion in the embryo.

The recorded data for the effect of strain on the studied parameter showed that the brown strain was higher $(0.84 \%)$ than the white one $(0.62 \%)$. Also, the recorded data for the effect of season on the studied parameter showed that, winter recorded lower $(0.61 \%)$ than in summer $(0.85 \%)$.

The interaction between strain and season was not significant. However, the difference between brown and white breeder was higher at summer season $(0.33 \%)$ than those belongs to white $(0.14)$ for the mentioned parameter. While, the interactions between season and breeder's age and between strain and breeder's age were significant $(P \leq 0.001)$. The interaction between the three main effects was significant $(P \leq 0.01)$.

\section{4- Effect of strain, season and breeder's age on lymphoid organs}

The data in Table (4) showed that the strain, season and breeder's age were not significantly affected spleen weight percentage throughout the experimental period. Our results agree with El-Sabry et al (2013) who found that breeder's age did not significantly affected relative organ weights. The spleen weight of early hatch $(\mathrm{EH})$ chicks were heavier than those of late hatch $(\mathrm{LH})$ chicks $(P \leq 0.05)$. Because spleen is the main lymphoid organs of the immune system, the heavier weight may show the early maturation of the organs of EH chicks (Van de Ven et al 2013).

Data concerning the interaction between strain and season and between season and age were significant $(P \leq 0.05)$.these may be due to the additive effect of these factors on spleen weight percentage. While the other types of interaction were not significant.

Bursa percentage data showed that the either strain or season did not significantly affected the relative bursa weight throughout the experimental period. However, the breeder's age effect in bursa percentage had significantly $(\mathrm{P} \leq 0.01)$. 
Table 4. Effect of strains, season and breeder's age on lymphoid organs

\begin{tabular}{|c|c|c|c|c|c|c|c|c|c|}
\hline & \multicolumn{2}{|c|}{ Strain } & \multicolumn{2}{|c|}{ Season } & \multicolumn{5}{|c|}{ Age } \\
\hline & White & Brown & Summer & Winter & 28 & 36 & 46 & 55 & 66 \\
\hline $\begin{array}{c}\text { Spleen } \\
\text { weight \% }\end{array}$ & $\begin{array}{c}0.084 \\
\pm 0.041\end{array}$ & $\begin{array}{c}0.046 \\
\pm 0.017\end{array}$ & $\begin{array}{c}0.078 \\
\pm 0.037\end{array}$ & $\begin{array}{c}0.052 \\
\pm 0.020\end{array}$ & $\begin{array}{l}0.0247 \\
\pm 0.007\end{array}$ & $\begin{array}{c}0.094 \\
\pm 0.039\end{array}$ & $\begin{array}{l}0.039 \\
\pm 0.01\end{array}$ & $\begin{array}{c}0.027 \\
\pm 0.006\end{array}$ & $\begin{array}{c}0.142 \\
\pm 0.082\end{array}$ \\
\hline $\begin{array}{c}\text { Bursa } \\
\text { weight } \%\end{array}$ & $\begin{array}{c}0.118 \\
\pm 0.021\end{array}$ & $\begin{array}{c}0.091 \\
\pm 0.026\end{array}$ & $\begin{array}{c}0.1055 \\
\pm 0.0185\end{array}$ & $\begin{array}{c}0.1039 \\
\pm 0.0296\end{array}$ & $\begin{array}{c}0.12125^{b} \\
\pm 0.0205\end{array}$ & $\begin{array}{l}0.1515^{a} \\
\pm 0.0485\end{array}$ & $\begin{array}{l}0.0995^{\mathrm{ab}} \\
\pm 0.0215\end{array}$ & $\begin{array}{l}0.061^{b} \\
\pm 0.023\end{array}$ & $\begin{array}{l}0.09025^{b} \\
\pm 0.00675\end{array}$ \\
\hline & Strains & Season & Age & $\mathrm{St}^{\star} \mathrm{Se}$ & $\mathrm{St}^{\star} \mathrm{A}$ & $\mathrm{Se}^{\star} \mathrm{A}$ & & $\mathrm{ST}^{\star} \mathrm{Se}^{\star A}$ & \\
\hline $\begin{array}{c}\text { Spleen } \\
\text { weight \% }\end{array}$ & NS & NS & NS & * & NS & * & & NS & \\
\hline $\begin{array}{c}\text { Bursa } \\
\text { weight \% }\end{array}$ & NS & NS & ** & $* * *$ & * & $* * *$ & & ** & \\
\hline
\end{tabular}

$a, b$ and $c$ Means within the same column with different letters are significantly differed. $S t=$ strain, $S e=s e a s o n, A=a g e$, $\mathrm{NS}=$ not significant, ${ }^{*}=\mathrm{P} \leq 0.05,{ }^{* *}=\mathrm{P} \leq 0.01,{ }^{* * *}=\mathrm{P} \leq 0.001$

Conversely to our results El-Sabry et al (2013) showed that early hatch $(\mathrm{EH})$ chicks had relative weights of the bursa similar to those of late hatch (LH). Van de Ven et al (2013) reported that hatch time influenced heart and bursa weight.

The analysis variance indicated that, there were a significant interaction effect on such parameter.

\section{REFERENCES}

Almeida, J.G., Vieira, S.L., Reis, R.N., Berres, J., Barros, R., Ferreira, A.K. and Furtado, F.V.F. 2008. Hatching distribution and embryo mortality of eggs laid by broiler breeders of different ages. Brazilian J. Poult. Sci., 10, 89-96.

Angel, R. 2007. Metabolic disorders: limitations to growth of and mineral deposition into the broiler skeleton after hatch and potential implications for leg problems. J. Appl. Poult. Res., 16, 138-149.

Azzam, M.A. and Mortola, J.P. 2007. Organ growth in chicken embryos during hypoxia: Implications on organ "sparing" and "catch-up growth". Respir. Physiol. Neurobiol, 159, 155-162.

Benton, C.E. and Brake, J. 1996. The effect of broiler flock age and length of egg storage on egg albumen during early incubation. Poult. Sci., 75, 1069-1075.

Brake, J., Walsh, T.J., Benton, C.E., Petitte, J.N., Meijerhof, R. and Penalva, G. 1997. Egg handling and storage. Poult. Sci., 76,144-151.
Callis, T.E., Chen, J.F. and Wang, D.Z. 2007. MicroRNAs in skeletal and cardiac muscle development. DNA Cell Biol., 26, 219-225.

Christensen, V.L. 2009. Development during the first seven days post-hatching. Avian Biol. Res., 2, 27-33.

Christensen, V.L., Donaldson, W.E. and Mcmurtry, J.P. 1996. Physiological differences in late embryos from turkey breeders at different ages. Poult. Sci., 75, 172-178.

Collin, A., Berri, C., Tesseraud, S., Rodon, F.E., Skiba-Cassy, S., Crochet, S., Duclos, M.J., Rideau, N., Tona, K., Buyse, J., Bruggeman, V., Decuypere, E., Picard, M. and Yahav, S. 2007. Effects of thermal manipulation during early and late embryogenesis on thermotolerance and breast muscle characteristics in broiler chickens. Poult. Sci., 86, 795-800.

Dibner, J.J. Richards, J.D., Kitchell, M.I. and Quiroz, M.A. 2007. Metabolic challenges and early bone development. J. Appl. Poult. Res., 16, 126-137.

Druyan, S. 2010. The effects of genetic line (broilers vs. layers) on embryo development. Poult. Sci., 89, 1457-1467.

El-Sabry, M.I., Yalçın, S. and Turgay - İzzetoğlu, G. 2013. Interaction between breeder age and hatching time affects intestine development and broiler performance. Livest. Sci., 157, 612-617.

Everaert, D.N., Willemsen, H., De Smit, H., Witters, A., De Baerdemaeker, J., Decuypere, E. and Bruggeman, V. 2008. Comparison of a modern broiler and layer strain during embryon- 

for layer dead embryo

ic development and the hatching process. Br. Poult. Sci., 49, 574-582.

Feher, G. 1988. The process of hatching in geese and ducks. Anatomia, Histologia, Embryologia, 17, 107-120.

Foye, O.T., Uni, Z. And Ferket, P.R. 2006. Effect of in ovo feeding egg white protein, betahydroxy-beta-methylbutyrate, and carbohydrates on glycogen status and neonatal growth of turkeys. Poult. Sci., 85, 1185-1192.

Glick, B. 1967. Antibody and gland studies in cortisone and ACTH-injected birds. J. Immunol., 98, 1076-1084.

Gomes, F.S., Santos, G.C.F. and Silva, P.L. 2005. Efeito da linhagem e idade de reprodutoras pesadas na qualidade dos pintos de um dia. Revista Brasileira de Ciência Avícola; 3(supl): p. 19.

Gross, G.H. 1985. Innervation of the complexus ("hatching") muscle of the chick. J. of Com. Neur., 232, 180-189.

Havenstein, G.B., Ferket, P.R., Grimes, J.L., Qureshi, M.A. and Nestor, K.E. 2007. Comparison of the performance of 1966- versus 2003type turkeys when fed representative 1966 and 2003 turkey diets: growth rate, livability, and feed conversion. Poult. Sci., 86, 232-240.

John, T.M., George, J.C. and Moran Jr., E.T. 1987. Pre- and post-hatch ultrastructural and metabolic changes in the hatching muscle of turkey embryos from antibiotic and glucose treated eggs. Cytobios, 49, 197-210.

Johnston, S.A. and Gous, R.M. 2007. Modelling the changes in the proportions of the egg components during a laying cycle. Br. Poult. Sci., 48, 347-353.

Kidd, M.T. 2003. A treatise on chicken dam nutrition that impacts progeny. World's Poult. Sci. J., 59, 475-494.

Leksrisompong, N., Romero-Sanchez, H., Plumstead, P.W., Brannan, K.E. and Brake, J. 2007. Broiler incubation. 1. Effect of elevated temperature during late incubation on body weight and organs of chicks. Poult. Sci., 86, 2685-2691.

Leyendecker, M., Hamann, H., Hartung, J., Kamphues, J., Ring, C., Gluender, G., Ahlers, C., Sander, I., Neumann, U. and Distl, $O$. 2001b. Analysis of genotype-environment interactions between layer lines and housing systems for performance traits, egg quality and bone breaking strength $-2^{\text {nd }}$ communication: Egg quality traits. Züchtungskunde, 73, 308323.
Lindgren, I. and Altimiras, J. 2011. Sensitivity of organ growth to chronically low oxygen levels during incubation in Red Jungle fowl and domesticated chicken breeds. Poult. Sci., 90, 126-135.

Moran, Jr. E.T. 2007. Nutrition of the developing embryo and hatchling. Poult. Sci., 86, 10431049.

Mortola, J.P. and Al Awam, K. 2010. Growth of the chicken embryo: implications of egg size. Comp. Biochem. Physiol. A Mol. Integr. Physiol., 156, 373-379.

Niranjan, M., Sharma, R.P., Rajkumar, U., Chatterjee, R.N., Reddy, B.L.N. and Bhattcharya, T.K. 2008. Egg quality traits in chicken varieties developed for backyard poultry farming in India. Livestock Research for Rural Development, (2012):http://www.Irrd.ord//lrrd2012/nira20189.htm. Assesed May 25, 2012.

Oke, O.E., Obanla, L.O., Onagbesan, O.M. and Daramola, J.O. 2015. Growth trajectory of the nigerian indigenous and exotic strains of chicken embryos during incubation under nigerian condition. Pertanika. J. Trop. Agric. Sci., 38(1), $45-55$.

Padhi, M.K., Chatterjee, R.N., Haunshi, S. and Rajkumar, U. 2013. Effect of age on egg quality in chicken.). Ind. J. of Poult. Sci., 48(1), 122125.

Pulikanti, R., Peebles, E.D., Keirs, R.W., Bennett, L.W., keralapurath, M.M. and Gerard, P.D. 2010. Pipping muscle and liver metabolic profile changes and relationships in broiler embryos on days 15 and 19 of incubation. Poult. Sci., 89, 860-865.

Puvadolpirod, S. and Thaxton, J.P. 2000. Model of physiologi-cal stress in chickens. 5. Quantitative evaluation. Poult. Sci., 79, 377-382.

Puvadolpirod, S. and Thaxton, J.P. 2000a. Model of physiological stress in chickens. 1. Response parameters. Poult. Sci., 79, 363-369.

Puvadolpirod, S. and Thaxton, J.P. 2000b. Model of physiological stress in chickens. 2. Dosimetry of adrenocorticotropin. Poult. Sci., 79, 370-376.

Rajkumar, U., Sharma, R.P., rajaravindra, K.S., Niranjan, M., Reddy, B.L.N., Bhattacharya, T.K. and Chatterjee, R.N. 2009. Effect of genotype and age on egg quality traits in Naked neck chicken under tropical climate of India. Inter. J. of Poult. Sci., 8, 1151-1155.

Reijrink, I.A.M., Meijerhof, R., Kemp, B. and Van Den Brand, H. 2008. The chicken embryo and its micro environment during egg storage and 
early incubation. World's Poult. Sci. J., 64, 581 $-598$.

Rizzi, C. and Chiericato, G.M. 2005. Organic farming production. Effect of age on the productive yield and egg quality of hens of two commercial hybrid lines and two local breeds. Ital. J. Anim. Sci., 4, 160-162.

SAS 2009. Statistical analysis systems user's guide," Version 9.2. SAS Inst., Inc., Cary, NC. USA. 170p.

Silversides, F.G. and Scott, T.A. 2001. Effect of storage and layer age on quality of eggs from two lines of hens. Poult. Sci., 80, 1240-1245.

Stern, C.D. 1991. The sub-embryonic fluid of the egg of the domestic fowl and its relationship to the early development of the embryo. pp. 81-90 in: Avian Incubation. S.G. Tullett, Ed. Butterworth-Heinemann, London, UK.

Suk, Y.O. and Park, C. 2001. Effect of breed and age of hen on the yolk to albumen ratio in two different genetic stocks. Poult. Sci., 80, 855858.

Tona, K., Agbo, K. Kamers, B., Everaert, N., Willemsen, H., Decuypere, E. and Gbeassor, M. 2010. Comparison of Lohmann White and Lohmann Brown Strains in Embryo Physiology. Inter. J. of Poult. Sci., 9(9), 907-910.

Tumova, E. and Gous, R.M. 2012. Interaction of hen production type, age and temperature on laying pattern and egg quality. Poult. Sci., 91, 1269-1275.

Tůmová, E., Skřivan, M., Mandák, K., 1993. Technological value of eggs of Hisex Brown and D 29 laying hens. Sborník VŠz v Praze, AF, rada $B ., 55,245-251$.

Uni, Z., Ferket, P.R., Tako, E. and Kedar, O. 2005. In ovo feeding improves energy status of late-term chicken embryos. Poult. Sci., 84, 764770.

Uni, Z., Yadgary, L. and Yair, R. 2012. Nutritional limitations during poultry embryonic development. J. Appl. Poult. Res. 21, 175-184.

Van de Ven, L.J.F., van Wagenberg, A.V., Decuypere, E., Kemp, B. and van den Brand, H. 2013. Perinatal broiler physiology between hatching and chick collection in 2 hatching systems. Poult. Sci., 92, 1050 - 1061.

Van den Brand, H., Parmentier, H.K. and Kemp, B. 2004. Effects of housing system (outdoor vs. cages) and age of laying hens on egg characteristics. Br. Poult. Sci., 45, 745-752.
Vieira, S.L., Almeida, J.G., Lima, A.R., Conde, O.R.A. and Olmos, A.R. 2005. Hatching distribution of eggs varying in weight and breeder age. Braz. J. Poult. Sci., 7, 73-78.

Warner, J.D., Ferket, P.R., Christensen, V.L. and Felts, J.V. 2006. Effect of season, hatch time, and post-hatch holding on glycogen status of turkey poults. Poult. Sci., 85(1), 56-57.

Williams, A.H., Liu, N., Van Rooij, E. and Olson, E.N. 2009. MicroRNA control of muscle development and disease. Curr. Opin. Cell Biol., 21, 461-469.

Wolanski, N.J., Renema, R.A., Robinson, F.E. Carney, V.L. and Fancher, B.I. 2007. Relationships Among Egg Characteristics, Chick Measurements, and Early Growth Traits in Ten Broiler Breeder Strains. Poult. Sci., 86, 1784-1792.

Wolanski, N.J., Renema, R.A., Robinson, F.E., Carney, V.L. and Fancher, B.I. 2006. Relationship between chick conformation and quality measures with early growth traits in males of eight selected pure or commercial broiler breeder strains. Poult. Sci., 85, 1490-1497.

Xiang-guang L., Xue-ling C. and Xiu-qi W. 2013. Changes in relative organ weights and intestinal transporter gene expression in embryos from white Plymouth Rock and WENS Yellow Feather Chickens. Comparative Biochemistry and Physiology, Part A 164, 368-375.

Yalçın, S., Cabuk, M., Bruggeman, V., Babaanoglu, E., Buys, J., Decuypere, E. and Siegel, P.B. 2008. Acclimation to heat during incubation. 1. Embryonic morphological traits, blood biochemistry, and hatching performance. Poult. Sci., 87, 1219-1228.

Yildirim, I.E. 2005. Effects of breeder age and preincubation storage of eggs on hatchability, time of hatch and relative organ weight of quail chicks at hatch. Sout. Afri. J. of Anim. Sci., 35 (2), 135-142.

Zamudio, S. 2003. The placenta at high altitude. High Alt. Med. Biol. 4, 171-191.

Zemková, L'., Simeonovová, J., Lichovníková, M. and Somerlíková, K. 2007. The effects of housing systems and age of hens on the weight and cholesterol concentration of the egg. Czech J. Anim. Sci., 52, 110-115.

Zhang, H. and Burggren W.W. 2012. Hypoxic level and duration differentially affect embryonic organ system development of the chicken (Gallus gallus). Poult. Sci., 91, 3191-3201. 